\title{
SPONTANEOUS RUPTURE OF UMBILICAL HERNIA IN AN INFANT
}

\author{
By S. L. Strange, M.B., F.R.C.S.Ed., D.T.M. \\ Senior Surgical Registrar, Whittington Hospital, London
}

Umbilical hernia in infants is remarkable both for its frequent occurrence and the rarity of any dangerous complications. In a recent paper, Grace Woods (I953) emphasized these points and stated that no case of strangulation has been recorded. A dangerous complication that has been recorded is spontaneous rupture and a further case of this is reported here. This complication is exceedingly rare even though the coverings of the sac are frequently very thin.

\section{Case Report}

On the afternoon of March 23, 1948, a male Chinese child, aged three months, was brought into the English Presbyterian Mission Hospital, Swatow, South China, with coils of small intestine lying on its anterior abdominal wall.

Three weeks previously he had been given away as an unwanted child and his foster-mother brought him to hospital. She stated that the umbilicus had looked normal until two days previously (March 2I) when it first protruded about $I$ in. on crying. The hernia was not treated by native medicine or other device. On the morning of March 23, when at the breast and 'taking the milk too fast,' according to his foster-mother, the hernia ruptured and intestine came out. $\mathrm{He}$ vomited several times and was in poor condition when brought to hospital about eight hours later, but there was no gross malnutrition. Coils of small intestine were protruding through the ruptured umbilicus and the skin tags and other hernial covering were seen around the edge of the umbiliçal orifice. There were no signs of inflammation or ulceration.
Operation was done under ether anaesthesia. The coils of intestine were washed with saline, the umbilical orifice enlarged, the intestine replaced and the wound closed. Though the infant survived the operation he died three days later.

\section{Discussion}

The only other similar case in an infant found in the literature is that reported by MacLean (1950) in which spontaneous rupture also occurred at the age of three months in a male infant, but operation was followed by recovery.

Two cases have been reported in children. Von Arnold (r860) reported spontaneous rupture of an umbilical hernia in a child aged four when extrusion of intestine occurred through the very wide umbilical ring. The child died. Porcher (1883), quoted by Johnson (1902), recorded the other case in a Negro girl aged 13. After spontaneous rupture of her umbilical hernia, omentum was extruded but operation was followed by recovery.

\section{Summary}

I. A case is described of spontaneous rupture of an umbilical hernia in a male infant aged three months.

2. Only one other similar case could be traced in the literature.

\section{BIBLIOGRAPHY}

ARNOLD, v. (1860), Mitt. bad. dratl. Ver., 14, 7.

JOHNSON, J. T. (1902), Trans. sth. surg. gynec. Ass., Nashville, Tenn., 14, 257.

MACLEAN, A. B. (1950), Brit. F. Surg., 38, 239.

PORCHER, W. P. (1883), N.C. med. F., 12, 266, cited by John son WOODS, G. E. (1953), Archives of Disease in Childhood, 28, 450.

\footnotetext{
Continued from page 32-Fohn Hankinson and Luis V. Amador.

SPIEGEL, E. A., and WYCIS, H. T. (1950), Arch. Neurol., 64, 295.

SPIEGEL, E. A., WYCIS, H. T., and THUR, C. (I951), $\mathfrak{F}$. Neurosurg., 8, 452.

SPIEGEL, E. A., and WYCIS, H. T. (1952), Acta Neurochir., 2, 3-4, 417. SPIEGEL, E. A., and WYCIS, H. T. (1952), 'Stereoencephalotomy,'
Grune and Stratton, New York.

STEIN, S. N., and PETERSON, W. (1950), Proc. Soc. Exp. Biol. Med., 74, 583 .

TALAIRACH, J., HECAEN, H., DAVID, M., MONNIER, M., and AJURIAGUERRA, J. (1949), Rev. Neurol., 81, 4.

THORNE, H. (195I), Sven Tandlak. Tskr., 44, 30.

TORRES BANQUERI, J. (1951), Clin. y Laboratorio, 51, 26.

UCHIMURA, Y., and NARABAYASHI, H. (1950), 'Stereoencephalotomy,' 47th fapanese Neuro-Psychiatric 'Conference, Kyoto.

WADA, TOYOJI (1951), Folia Psychiat. et Neurol., Fapan, 4, 309. WYCIS, H. T., SOLOFF, L., and SPIEGEL, E. A. (1950), Arch. Neurol., 63, 1004 .

WYCIS, H. T,; and SPIEGEL, E. A. (1949), Proc. Roy. Soc. Med., 42, (Suppl.) 12.

WYCIS, H. T., and SPIEGEL, E. A. (1949), N.Y. St. F. Med., 49, 2275.

WYCIS, H. T., and SPIEGEL, E. A. (1950), 'Surgical Forum, Proc. Clin. Cong. Amer. Col.' Surg., 329.

WYCIS, H. T., and SPIEGEL, E. A. (1952), Confinia Neurologica; 12, 245.
} 